\title{
EVALUASI USABILITY SISTEM APLIKASI MOBILE JKN MENGGUNAKAN USE QUESTIONNAIRE
}

\author{
Baginda Oloan Lubs ${ }^{1}$, Agus Salim ${ }^{2}$, Jefi ${ }^{3}$ \\ ${ }^{1,2)}$ Sistem Informasi Universitas Bina Sarana Informatika \\ Jl. Kamal Raya No.18 Ringroad Barat, Cengkareng, Jakarta \\ ${ }^{3)}$ Teknologi Informasi Universitas Bina Sarana Informatika \\ Jl. Kamal Raya No.18 Ringroad Barat, Cengkareng, Jakarta \\ Email: baginda.bio@bsi.ac.id, agus.salim@bsi.ac.id,jefi.jfi@bsi.ac.id
}

\begin{abstract}
This study aims to find out how superior and important is the application of information technology to produce an information system that is useful for answering user needs, by evaluating and analyzing information systems that have been embedded on the smartphone (smartphone) of the user who uses. Where the intended application is Mobile JKN (BPJS Health Application).

The analysis was carried out to recognize the strengths and weaknesses of the system used by the user by measuring the usability of the system using the Use Questionnaire, in which there are several aspects of usability measurement according to IDO, namely efficiency, effectiveness and satisfaction, where these points become a reference for evaluating and analyzing an information system.

The results of this study will show that there are several advantages or strengths of the system that can support the development and progress of this application, but the results of this study also show the weaknesses and weaknesses of the system, so that the existing system needs to be improved or improved towards a better direction.
\end{abstract}

Keyword : Usability, Mobile JKN, Use Quesionnaire

\section{PENDAHULUAN}

Perkembangan teknologi informasi dan telekomunikasi semakin pesat, diantaranya penggunaan perangkat telepon pintar yang saat ini sudah dimiliki sebagian masyarakat. Jumlah pengguna telepon pintar di Indonesia diperkirakan mencapai lebih dari 100 juta orang. Selain itu, trend teknologi saat ini mengarah ke penggunaan mobile application, mobile application yang banyak digunakan seperti media sosial saja mencapai 92 juta pengguna atau sekitar $32 \%$ dari populasi. Faktanya, populasi penduduk Indonesia saat ini didominasi oleh generasi muda yang mengikuti perkembangan teknologi, oleh karenanya penting untuk menyesuaikan 
diri dengan trend teknologi saat ini.(Humas, 2017). Melihat semakin banyak masyarakat yang menggunakan perangkat tersebut, BPJS Kesehatan pun tak ketinggalan. Dalam rangka meningkatkan pelayanan terhadap peserta Jaminan Kesehatan NasionalKartu Indonesia Sehat (JKN-KIS), BPJS Kesehatan meluncurkan aplikasi Mobile JKN (Humas, 2017). Mobile JKN yang berbasis android merupakan aplikasi yang memerlukan pengujian apakah aplikasi tersebut diterima oleh penggunanya dengan baik. Dalam hal ini peneliti melakukan pengujian sistem usabilitynya. Antarmuka (Interface) Android didasarkan pada manipulasi langsung menggunakan sentuhan yang serupa dengan tindakan di dunia nyata, seperti menggesek (swiping), mengetuk (tapping), mencubit (pinching), dan membalikkan cubitan untuk memanipulasi obyek di layar.

Umumnya, dalam pengembangan dan implementasi perangkat lunak jarang sekali dilakukan uji usability, karena mereka berkutat pada masalah pengelolaan data, kebutuhan, jadwal dan sumber daya yang tersedia bahkan sering terjadi perdebatan antara user dan pembuat system.(Suskamiyadi, Nurhadryani and Sukoco, 2017).
Kondisi tersebut mendorong dilakukan evaluasi sampai sejauh mana usability sebuah perangkat lunak yang telah digunakan. Hal mendasar yang dapat dijadikan parameter keberhasilan pengembangan sistem informasi ataupun perangkat lunak adalah usability.

Tingkat usability menentukan apakah sistem tersebut akan bermanfaat, diterima dan bertahan lama dalam penggunaannya. Sistem dengan usability yang tinggi akan membuat sistem tersebut populer dalam waktu yang lama karena banyak orang akan merasakan manfaatnya. Sedangkan, sistem dengan usability rendah, meskipun dibuat berdasarkan kebutuhan, dan menghabiskan sumber daya yang tidak sedikit, seringkali pada akhirnya diabaikan.(Toy and Supriyanti, 2014) .

Evaluasi merupakan kegiatan terencana untuk menilai suatu permasalahan yang terjadi dengan menggunakan instrumen dan hasilnya dapat dibandingkan dengan tolok ukur untuk memperoleh kesimpulan sehingga ditemukan solusi untuk menyelesaikan permasalahan yang timbul.(Supriyatna and Maria, 2018). Selain itu Kualitas perangkat lunak adalah ukuran yang menunjukkan ketercapaian terhadap standar kualitas yang diacu. Kualitas 
menjadi salah satu faktor penentu kesuksesan sebuah perangkat lunak (Marthasari and Hayatin, 2017).

\section{LANDASAN TEORI}

\section{Pengertian Usability}

Dalam penelitian (Istiana, 2015) mengemukakan bahwa menurut Joseph Dumas dan Janice Redish usability adalah mengacu kepada bagaimana pengguna bisa mempelajari dan menggunakan produk untuk memperoleh tujuannya dan seberapa puaskah mereka terhadap penggunannya.

Berdasarkan definisi tersebut usability diukur berdasarkan komponen: (Yumarlin MZ, 2016)

a. Kemudahan (learnability)

b. Efisiensi (efficiency)

c. Mudah diingat (memorability)

d. Kesalahan dan keamanan (errors)

e. Kepuasan (satisfaction)

\section{Pengukuran Usability}

Mengukur usability berarti mengukur efektifitas, efisiensi dan kepuasan user. Untuk itu dapat dilakukan dua cara yaitu

a. Mengandalkan asumsi pembuat program atau diri sendiri

b. Menggunakan usability metric.
Menurut Tullis \& Albert dalam (Aelani and Falahah, 2012) Hasil pengukuran usability dapat dimanfaatkan untuk beberapa hal berikut:

a. Mendapatkan masukan dari data, lebih obyektif daripada pendapat sendiri.

b. Dapat digunakan untuk membandingkan usability dua produk

c. Dapat mengklasifikasi permasalahan (jika ada)

d. Membuat prediksi penggunaan produk yang sebenarnya

e. Memberikan ilustrasi pada manajemen berdasarkan fakta.

Menurut Perlman dalam (Aelani and Falahah, 2012) Pada umumnya, pengukuran usability dilakukan menggunakan serangkaian kuisioner.

\section{Android}

Android (/'æn.drord/; AN-droyd) adalah sistem operasi berbasis Linux yang dirancang untuk perangkat seluler layar sentuh seperti telepon pintar dan komputer tablet. Android adalah sistem operasi dengan sumber terbuka, dan Google merilis kodenya di bawah Lisensi Apache.

Kode dengan sumber terbuka dan lisensi perizinan pada Android memungkinkan perangkat lunak untuk 
dimodifikasi secara bebas dan android versi $4.0 \mathrm{ke}$ atas dan sistem iOS didistribusikan oleh para pembuat 10. Setelah aplikasi itu terpasang, peserta perangkat, operator nirkabel, dan pengembang aplikasi.

Selain itu, Android memiliki sejumlah besar komunitas pengembang aplikasi (apps) yang memperluas fungsionalitas perangkat, umumnya ditulis dalam versi kustomisasi bahasa pemrograman Java (Rahadi, 2014)

\section{Aplikasi Mobile JKN}

Aplikasi Mobile JKN ini merupakan bentuk transformasi digital model bisnis BPJS Kesehatan yang semula berupa kegiatan administratif dilakukan di Kantor Cabang atau Fasilitas Kesehatan, ditransformasi kedalam bentuk Aplikasi yang dapat digunakan oleh peserta dimana saja kapanpun tanpa batasan waktu (self service). Saat ini tercatat pengguna Aplikasi Mobile JKN versi Android sebanyak > 1.000.000 user dan Aplikasi Mobile JKN versi iOS sebanyak > 2.000 user (Humas, 2017).

Untuk menggunakan aplikasi Mobile JKN syaratnya sangat mudah, hanya perlu mengunduh aplikasi melalui Google Play Store dan Apple Store. Aplikasi ini direkomendasikan untuk telepon pintar yang menggunakan sistem 


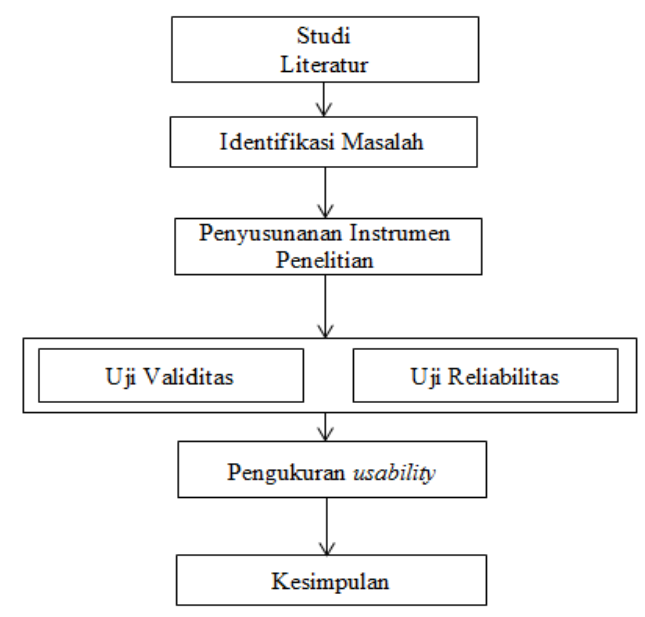

Gambar 1. Langkah-langkah Penelitian

\section{Pengumpulan Data}

Penelitian ini termasuk ke dalam penelitian deskriptif dengan pendekatan kuantitatif. Metode kuantitatif merupakan metode yang bisa digunakan untuk survey guna mendapatkan data yang telah terjadi pada masa lampau atau masa kini tentang pendapat, perilaku, keyakinan untuk menguji beberapa hipotesis (Warjiyono and Hellyana, 2018).

Metode pengumpulan data dilakukan dengan metode penyebaran kuesioner melalui media survei untuk mendapatkan data. Skala dalam kuesioner yang digunakan adalah dengan skala linkert. Menurut (Sugiyono, 2019) Skala Likert digunakan untuk mengukur sikap, pendapat, dan persepsi seseorang atau sekelompok orang tentang fenomena sosial yang merupakan skala kontinum bipolar, pada ujung sebelah kiri (angka rendah) menggambarkan suatu jawaban yang bersifat negative. Sedang ujung sebelah kanan (angka tinggi), menggambarkan suatu jawaban yang bersifat positif. Skala Likert dirancang untuk meyakinkan responden menjawab dalam berbagai tingkatan pada setiap butir pertanyaan atau pernyataan yang terdapat dalam kuesioner.

Data tentang dimensi dari variabelvariabel yang dianalisis dalam penelitian ini yang ditujukan kepada responden menggunakan skala 1 s/d 5 untuk mendapatkan data yang bersifat ordinal dan diberi skor.

Tabel 1. Tabel Nilai

\begin{tabular}{|c|c|c|c|c|c|}
\hline PK & STS & TS & N & S & SS \\
\hline Nilai & 1 & 2 & 3 & 4 & 5 \\
\hline
\end{tabular}

Sumber : (Sugiyono, 2019)

Keterangan :

PK = Pertanyaan Kuisioner

STS = Sangat Tidak Setuju

TS = Tidak Setuju

$\mathrm{N} \quad=$ Netral

$\mathrm{S} \quad=$ Setuju

SS = Sangat Setuju

\section{Pengujian Validitas dan Reliabilitas}

Kelayakan kuisioner dapat diukur menggunakan uji validitas dan uji reliabilitas. Analisis kelayakan diperlukan untuk membuktikan bahwa kuisioner telah memenuhi persyaratan alat ukur yang baik. Instrumen penelitian 
dikatakan memenuhi persyaratan jika dinyatakan valid dan reliabel. Instrumen yang valid menunjukkan bahwa data dari responden benar-benar valid dan mampu mengukur variabel-variabel yang akan diukur dalam penelitian.

Adapun instrumen dikatakan reliabel jika dapat dipercaya dan memberikan hasil yang konsisten dalam pengambilan data. Uji reliabilitas dilakukan untuk mengetahui konsistensi alat ukur dan apakah alat ukur tersebut dapat diandalkan dan tetap konsisten saat dilakukan pengukuran secara berulang.

Selain itu, uji ini digunakan untuk mengetahui apakah jawaban responden dapat digunakan pada tahap selanjutnya. Sebuah instrumen dapat dianggap reliabel jika dapat dipercaya sebagai alat ukur. Pada penelitian ini, uji reliabilitas dilakukan dengan menghitung nilai koefisien Cronbach's alpha (Marthasari and Hayatin, 2017).

Kedua pengujian ini diterapkan terhadap kuisioner penelitian untuk mengetahui validitas dan reliabilitasnya.

\section{Usability Testing}

Hasil pengukuran kemudian dioleh dengan metoda statistik deskriptif dan dilakukan analisis baik terhadap masingmasing parameter atau terhadap keseluruhan parameter. Saat ini, USE merupakan salah satu paket kuisioner non komersial yang dapat digunakan untuk penelitian usability sistem.

Kuisioner yang diberikan terdiri dari 10 pertanyaan, dan dari 10 pertanyaan tersebut telah cukup untuk menunjukkan nilai aspek-aspek usability. Brenda Battleson dalam (W et al., 2015) Hasil plot kelima aspek usability di atas terhadap 10 pertanyaan kuisioner dapat dilihat :

Tabel 2. Kuesioner USE

\begin{tabular}{|c|c|c|c|c|c|c|}
\hline \multirow{2}{*}{ No } & \multirow{2}{*}{ Pernyataan } & STS & TS & $\mathrm{N}$ & $\mathrm{S}$ & SS \\
\hline & & 1 & 2 & 3 & 4 & 5 \\
\hline \multicolumn{7}{|c|}{ ASPEK SISTEM (SYSTEM) } \\
\hline 1 & $\begin{array}{l}\text { Tampilan } \\
\text { aplikasi } \\
\text { Mobile JKN } \\
\text { mudah } \\
\text { dikenali. }\end{array}$ & & & & & \\
\hline 2 & $\begin{array}{l}\text { Aplikasi } \\
\text { Mobile JKN } \\
\text { mudah } \\
\text { dioperasikan. }\end{array}$ & & & & & \\
\hline 3 & $\begin{array}{l}\text { Kombinasi } \\
\text { warna enak } \\
\text { dilihat. }\end{array}$ & & & & & \\
\hline \multicolumn{7}{|c|}{ ASPEK PENGGUNA (USER) } \\
\hline 4 & $\begin{array}{l}\text { Tampilan } \\
\text { menu mudah } \\
\text { dikenali. }\end{array}$ & & & & & \\
\hline 5 & $\begin{array}{l}\text { Fasilitas cari } \\
\text { berfungsi } \\
\text { dengan baik. }\end{array}$ & & & & & \\
\hline 6 & $\begin{array}{l}\text { Aplikasi } \\
\text { Mobile JKN } \\
\text { mudah } \\
\text { dibaca. }\end{array}$ & & & & & \\
\hline 7 & Aplikasi & & & & & \\
\hline
\end{tabular}






Sumber : Hasil Olahan Data (2018)

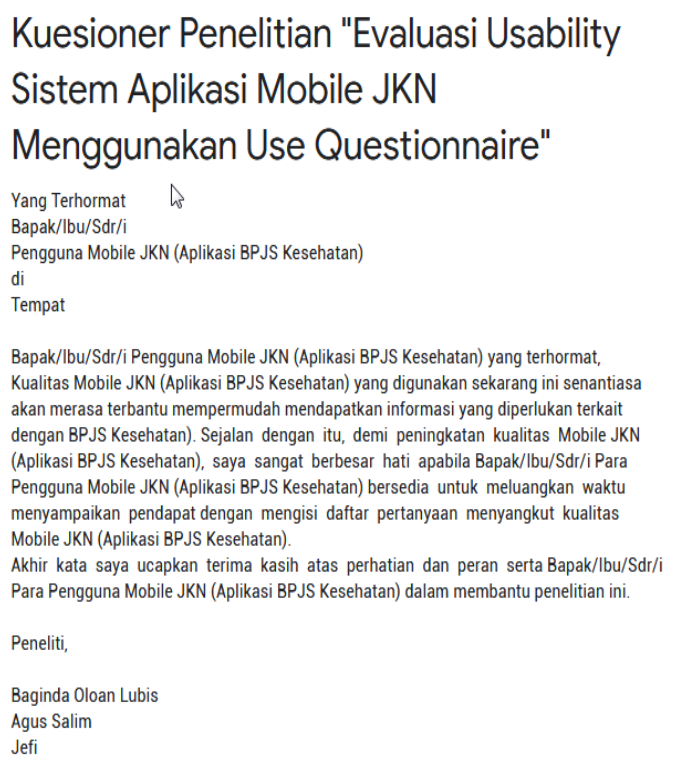

Gambar 2. Tampilan Form Kuesioner dengan Google Form

\section{HASIL DAN PEMBAHASAN}

\section{Deskripsi Responden}

Responden penelitian berjumlah 30 orang terdiri dari dosen dan karyawan Universitas Bina Sarana Informatika Jakarta. Dari hasil kuesioner dapat dijelaskan deskripsi responden berdasarkan: jenis kelamin, usia dan pendidikan terakhir.

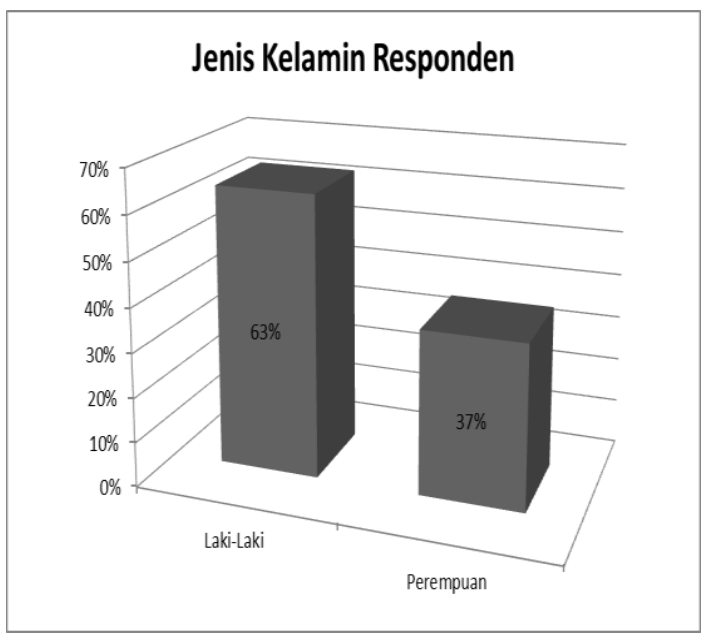

Gambar 3. Prosentase Jenis Kelamin

Responden

Deskripsi responden berdasarkan jenis kelamin laki-laki sebanyak 19 responden (63\%) dan perempuan sebanyak 11 responden (37\%). Ini menjalaskan bahwa jenis kelamin laki-laki lebih dominan menggunakan Aplikasi Mobile JKN dari responden yang terjaring. 


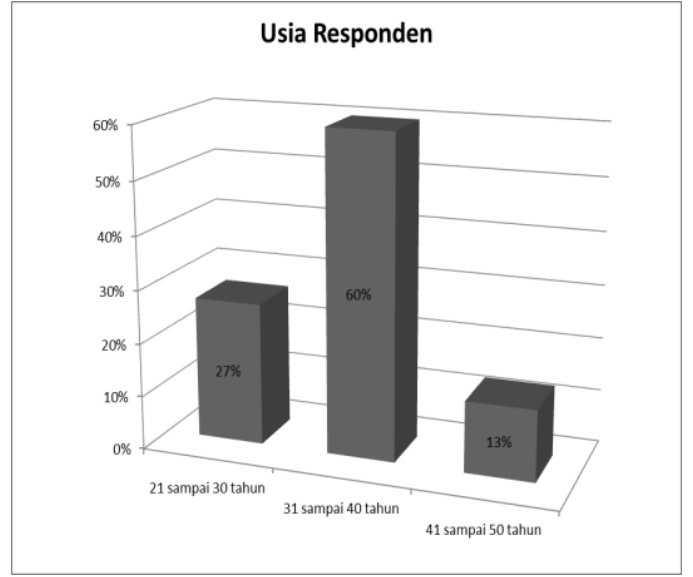

Gambar 4 Prosentase Usia Responden

Berdasarkan usia responden 21 sampai dengan 30 tahun sebanyak delapan responden (27\%), 31 sampai dengan 40 tahun sebanyak 18 responden (60\%) dan 41 sampai dengan 50 tahun sebanyak empat responden (13\%). Dari data tersebut usia responden yang menggunakan aplikasi Mobile JKN adalah usia 31 sampai dengan 40 tahun.

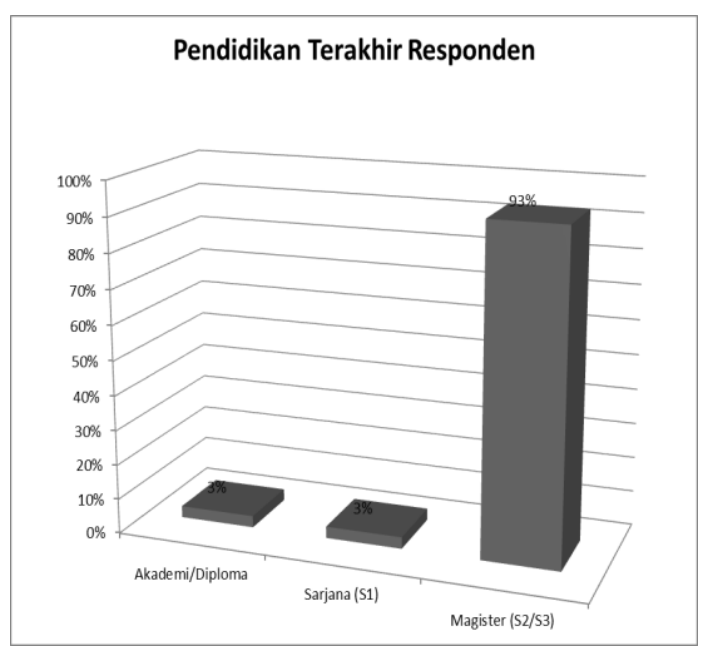

Gambar 5 Prosentase Pendidikan Responden

Berdasarkan pendidikan terakhir responden dengan pendidikan Akademi/Diploma sebanyak satu responden (3\%), Sarjana (S1) sebanyak satu responden (3\%) dan Magister (S2/S3) sebanyak 28 responden (93\%). Berdasarkan data responden yang terajaing terlihat yang dominan menggunakan aplikasi mobile JKN adalah yang berpendidikan Magister (S2/S3) sebanyak 93\%.

\section{Hasil Pengujian Validitas}

Uji validitas yang digunakan pada penelitian ini Uji Validitas Product Momen Pearson Correlation, yang menggunakan prinsip mengkorelasikan atau menghubungkan antara masingmasing skor item dengan skor total yang diperoleh dalam penelitian. Setiap uji dalam statistik tentu mempuyai dasar dalam pengambilan keputusan sebagai acuan untuk membuat kesimpulan, begitu pula Uji Validitas Product Momen Pearson Correlation, dalam uji validitas ini, dasar pengambilan keputusannya adalah sebagai berikut:

a. Jika nilai rhitung lebih besar dari nilai rtabel, maka angket tersebut dinyatakan valid

b. Jika nilai rhitung lebih kecil dari nilai rtabel, maka angket tersebut dinyatakan tidak valid (Sugiyono, 2019) 
Sebelum dilakukan pengujian validitas terlebih dahulu ditentukan taraf nyata $(\alpha)$ yaitu $5 \%$ atau 0,05 dan statistik uji yang digunakan adalah (rhoSpearman).Nilai kritis $=$ nilai tabel dimana $\mathrm{n}=30 . \mathrm{r}$ tabel $=\mathrm{r} \alpha ;(\mathrm{n}-2)=$ $\mathrm{r} 0,05 ;(28)=0,375$.

Tabel 3. Perbandingan Hasil Pengujian $r$ Hitung dengan r Tabel Uji Validitas Aspek

Sistem

\begin{tabular}{|l|l|l|l|}
\hline Pernyataan & $\begin{array}{l}\mathrm{r} \\
\text { Hitung }\end{array}$ & $\begin{array}{l}\mathrm{r} \\
\text { Tabel }\end{array}$ & Keputusan \\
\hline AS1 & 0,783 & 0,375 & Valid \\
\hline AS2 & 0,799 & 0,375 & Valid \\
\hline AS3 & 0,818 & 0,375 & Valid \\
\hline
\end{tabular}

Sumber : Data Olahan (2018)

Berdasarkan hasil uji coba instrumen penelitian diperoleh dari tabel 3 dapat disimpulkan bahwa ke tiga item pernyataan dinyatakan valid.

Tabel 4. Perbandingan Hasil Pengujian $r$ Hitung dengan $r$ Tabel Uji Validitas Aspek Pengguna

\begin{tabular}{|l|l|l|l|}
\hline Pernyataan & $\begin{array}{l}r \\
\text { Hitung }\end{array}$ & $\begin{array}{l}\mathrm{r} \\
\text { Tabel }\end{array}$ & Keputusan \\
\hline AP1 & 0,480 & 0,375 & Valid \\
\hline AP2 & 0,718 & 0,375 & Valid \\
\hline AP3 & 0,864 & 0,375 & Valid \\
\hline AP4 & 0,543 & 0,375 & Valid \\
\hline AP5 & 0,818 & 0,375 & Valid \\
\hline
\end{tabular}

Sumber : Data Olahan (2018)

Berdasarkan hasil uji coba instrumen penelitian diperoleh dari tabel
4 dapat disimpulkan bahwa ke lima item pernyataan dinyatakan valid.

Tabel 5. Perbandingan Hasil Pengujian $r$ Hitung dengan r Tabel Uji Validitas Aspek Interaksi

\begin{tabular}{|l|l|l|l|}
\hline Pernyataan & $\begin{array}{l}\mathrm{r} \\
\text { Hitung }\end{array}$ & $\begin{array}{l}\mathrm{r} \\
\text { Tabel }\end{array}$ & Keputusan \\
\hline AI1 & 0,809 & 0,375 & Valid \\
\hline AI2 & 0,874 & 0,375 & Valid \\
\hline
\end{tabular}

Sumber : Data Olahan (2018)

Berdasarkan hasil uji coba instrumen penelitian diperoleh dari tabel 5 dapat disimpulkan bahwa ke dua item pernyataan dinyatakan valid.

\section{Hasil Pengujian Reliabilitas}

Uji reliabilitas dapat dilakukan secara bersama-sama terhadap seluruh butir atau item pertanyaan dalam kuesioner penelitian. Dasar pengambilan keputusan dalam uji reliabilitas:

a. Jika nilai Cronbach's Alpha $>0,60$ maka kuesioner atau angket dinyatakan reliabel atau konsisten.

b. Juka nilai Cronbach's Alpha $<0,60$ maka kuesioner atau angket dinyatakan tidak reliabel atau tidak konsisten. 
Tabel 6. Perbandingan Hasil Pengujian

Reliabilitas Masing-Masing Pernyataan

\begin{tabular}{|l|l|l|l|}
\hline Pernyataan & $\begin{array}{l}\text { Nilai } \\
\text { Croanbach 's } \\
\text { Alpha }\end{array}$ & $\begin{array}{l}\mathrm{r} \\
\text { Tabel }\end{array}$ & Keterangan \\
\hline AS1 & 0,844 & 0,60 & Reliable \\
\hline AS2 & 0,864 & 0,60 & Reliable \\
\hline AS3 & 0,838 & 0,60 & Reliable \\
\hline AP1 & 0,847 & 0,60 & Reliable \\
\hline AP2 & 0,863 & 0,60 & Reliable \\
\hline AP3 & 0,833 & 0,60 & Reliable \\
\hline AP4 & 0,857 & 0,60 & Reliable \\
\hline AP5 & 0,834 & 0,60 & Reliable \\
\hline AI1 & 0,840 & 0,60 & Reliable \\
\hline AI1 & 0,843 & 0,60 & Reliable \\
\hline
\end{tabular}

Sumber : Data Olahan (2018)

Keseluruhan pernyataan menunjukkan nilai Cronbach's Alpha yang lebih besar 0,60 sehingga seluruh pernyataan dinyatakan Reliable.

\section{Pengukuran Usability}

Tabel 7. Rekap Nilai Usability

\begin{tabular}{|c|l|l|}
\hline No & Pernyataan & Nilai \\
\hline ASPEK SISTEM (SYSTEM) \\
\hline 1 & $\begin{array}{l}\text { Tampilan aplikasi Mobile } \\
\text { JKN mudah dikenali. }\end{array}$ & 4,20 \\
\hline 2 & $\begin{array}{l}\text { Aplikasi Mobile JKN } \\
\text { mudah dioperasikan. }\end{array}$ & 4,37 \\
\hline 3 & $\begin{array}{l}\text { Kombinasi warna enak } \\
\text { dilihat. }\end{array}$ & 4,13 \\
\hline ASPEK PENGGUNA (USER) & 4,20 \\
\hline 4 & $\begin{array}{l}\text { Tampilan menu mudah } \\
\text { dikenali. }\end{array}$ & 3,80 \\
\hline 5 & $\begin{array}{l}\text { Fasilitas cari berfungsi } \\
\text { dengan baik. }\end{array}$ & 4,27 \\
\hline 6 & $\begin{array}{l}\text { Aplikasi Mobile JKN } \\
\text { mudah dibaca. }\end{array}$ & 4,43 \\
\hline 7 & $\begin{array}{l}\text { Aplikasi Mobile JKN } \\
\text { mudah di download. }\end{array}$ & 4,07 \\
\hline 8 & $\begin{array}{l}\text { Symbol-simbol gambar } \\
\text { mudah dipahami. }\end{array}$ \\
\hline
\end{tabular}

\begin{tabular}{|c|l|c|}
\hline \multicolumn{3}{|c|}{ ASPEK INTERAKSI (INTERACTION) } \\
\hline 9 & $\begin{array}{l}\text { Akses Informasi Aplikasi } \\
\text { Mobile JKN mudah } \\
\text { diperoleh. }\end{array}$ & 4,30 \\
\hline 10 & $\begin{array}{l}\text { Aplikasi Mobile JKN } \\
\text { sesuai kebutuhan. }\end{array}$ & 3,90 \\
\hline
\end{tabular}

Sumber : Data Olahan (2018)

Berdasarkan rekap nilai Usability dapat dianalisa sebagai berikut:

1. Nilai Learnability (fungsi-fungsi dasar produk mudah dioperasikan sejak awal), dapat dilihat dari ratarata hasil aspek system dan pengguna sebesar 4,18.

2. Nilai Efficiency (fungsi-fungsi produk dapat dengan cepat dipergunakan), dapat dilihat pada fasilitas pencarian sebesar 3,80.

3. Nilai Satisfaction (seberapa puaskah pengguna?), dapat dilihat dari ratarata hasil keseluruhan aspek sebesar 4,17 .

Selain berdasarkan rekap nilai usability tigkat usability kemudian diukur menggunakan Frekuensi relatif. Hasil perhitungan dibandingkan dengan standar pada tabel dibawah ini. 
Tabel 8. Standar Kelayakan sistem

\begin{tabular}{|l|l|}
\hline Angka $(\%)$ & Kategori \\
\hline Angka $<21$ & $\begin{array}{l}\text { Sangat Tidak } \\
\text { Layak }\end{array}$ \\
\hline Angka $\leq 21$ angka $<40$ & Tidak Layak \\
\hline Angka $\leq 40$ angka $<60$ & Cukup \\
\hline Angka $\leq 60$ angka $<80$ & Layak \\
\hline $\begin{array}{l}\text { Angka } \leq 80 \text { angka } \leq \\
100\end{array}$ & Sangat Layak \\
\hline
\end{tabular}

Sumber : (Marthasari and Hayatin, 2017)

Hasil perhitungan dibandingkan dengan standar pada Tabel 8 Skor yang diobservasi didapatkan dari skor total jawaban 30 responden adalah 1252, sedangkan skor yang diharapkan diperoleh dari jumlah skor maksimal skala dikalikan dengan jumlah pertanyaan lalu dikalikan dengan jumlah responden yaitu $5 \times 10 \times 30=1500$. Selanjutnya dengan menggunakan persamaan.

$$
\frac{f i}{\Sigma f_{i}} x 100 \%=\frac{f_{i}}{n} x 100 \%
$$

Keterangan :

$f \quad$ frekuensi

$\sum f \mathrm{i} \quad$ Jumlah dari frekuensi yang ke i

$\mathrm{n} \quad$ komponen

maka kelayakan sistem yang diperoleh adalah $83,5 \%$. Nilai tersebut termasuk dalam kategori "Sangat Layak".

\section{SIMPULAN}

Berdasarkan hasil rekap nilai usability aspek sistem (system) yang memperoleh rata-rata 4,18 dapat disimpulkan bahwa aspek sistem sangat baik, kemudian aspek pengguna (user) memperoleh nilai 3,80 disini dapat disimpulkan bahwa aspek user masuk kategori baik.

Dan yang terakhir aspek interksi (interaction) menperoleh nilai sebesar 4,17 nilai ini menunjukkan aspek interaksi dikategori sangat baik, dapat disimpulkan bahwa Mobile JKN telah memiliki aspek nilai usability yang sangat baik. Nilai atribut terkecil ada pada aspek user yaitu fasilitas pencarian yaitu 3,80, ini dapat dijadikan sebagai acuan untuk memperbaiki Aplikasi Mobile JKN.

Saran dari penelitian ini untuk kedepannya Aplikasi Mobile JKN tetap dipergunakan dan jika memungkinkan dikembangkan lagi. Kemudian untuk penelitian lebih lanjut, sebaiknya melakukan pengujian dengan model yang berbeda agar dapat dibandingkan dengan yang penulis lakukan. Jumlah responden untuk penelitian lebih lanjut sebaiknya ditingkatkan untuk mendapatkan ke akuratan datanya yang lebih baik.

\section{DAFTAR PUSTAKA}

Aelani, K. and Falahah (2012) 'PENGUKURAN USABILITY SISTEM MENGGUNAKAN USE 


\section{QUESTIONNAIRE (STUDI KASUS APLIKASI PERWALIAN ONLINE STMIK "AMIKBANDUNG" )', in Seminar Nasional Aplikasi Teknologi Informasi, pp. 1-6.}

Humas (2017) Akses Pelayanan Dalam Genggaman BPJS Kesehatan Luncurkan Aplikasi Mobile JKN, Banyak Manfaat dan Kemudahan Peserta JKN-KIS, BPJSKesehatan.go.id. Available at: https://www.bpjskesehatan.go.id/bpjs/index.php/pos t/read/2017/596/Akses-PelayananDalam-Genggaman-BPJS-

Kesehatan-Luncurkan-AplikasiMobile-JKN-Banyak-Manfaatdan-Mudahkan-Peserta-JKN-KIS.

Istiana, P. (2015) 'EVALUASI USABILITY SITUS WEB PERPUSTAKAAN', Visi Pustaka, 13(3), pp. 5-10.

Marthasari, G. I. and Hayatin, N. (2017) 'Analisis Usability Terhadap Sistem Lective Gegulang', Jurnal Seminar Nasional Teknologi dan Rekayasa (SENTRA), 1(1), pp. 18.

Rahadi, D. R. (2014) 'Pengukuran Usability Sistem Menggunakan Use Questionnaire Pada Aplikasi Android', Jurnal Sistem Informasi(JSI), 6(1), pp. 661-671.

Sugiyono (2019) Metode Penelitian Kuantitatif, Kualitatif, dan $R \& D$. 1st edn. Bandung: Alfabeta.

Supriyatna, A. and Maria, V. (2018) 'Analisa Tingkat Kepuasan Pengguna dan Tingkat Kepentingan Penerapan Sistem Informasi DJP Online dengan
Kerangka PIECES', Khazanah Informatika: Jurnal Ilmu Komputer dan Informatika, 3(2), p. 88. doi: 10.23917/khif.v3i2.5264.

Suskamiyadi, S., Nurhadryani, Y. and Sukoco, H. (2017) 'Pengembangan dan Uji Usability Sistem Informasi Manajemen Pemantauan Kehadiran dan Nilai Ujian Siswa', Jurnal Ilmu Komputer dan AgriInformatika, 3(1), p. 57. doi: 10.29244/jika.3.1.57-64.

Toy, A. and Supriyanti, W. (2014) 'Evaluasi Usability Aplikasi Jadwal Terpadu Universitas Muhammadiyah Surakarta Dengan Metode Kuisioner', Seminar Nasional Teknologi Informasi dan Multimedia 2014, 2(1), pp. 31-36.

W, M. A. D. et al. (2015) 'EVALUASI USABILITY UNTUK MENGUKUR PENGGUNAAN WEBSITE EVENT ORGANIZER', in Seminar Nasional Informatika 2015, pp. 428-434.

Warjiyono, W. and Hellyana, C. M. (2018) 'Pengukuran Kualitas Website Pemerintah Desa Jagalempeni Menggunakan Metode Webqual 4.0', Jurnal Teknologi Informasi dan Ilmu Komputer, 5(2), p. 139 . doi: 10.25126/jtiik.201852666.

Yumarlin MZ (2016) 'Evaluasi Penggunaan Website Universitas Janabadra Dengan Menggunakan Metode Usability Testing', Informasi Interaktif, 1(1), pp. 3443. Available at: http://www.ejournal.janabadra.ac.id/index.php/i nformasiinteraktif/article/view/345 